Pak. j. sci. ind. res. Ser. A: phys. sci. 2021 64A(1) 59-64

\title{
Source Rock Potential of Chichali and Samana Suk Formations Deposits in Panjpir Oilfield Subsurface, Punjab Platform, Pakistan
}

\author{
Syed Bilawal Ali Shah ${ }^{a *}$, Syed Haider Ali Shah ${ }^{b}$, Adeeb Ahmed ${ }^{c}$ and Muhammad Nofal Munir \\ ${ }^{a}$ Department of Geology, University of Malaya, Kuala Lumpur, 50603, Malaysia \\ ${ }^{b}$ Department of Management Sciences, Bahria University Islamabad, 44000, Pakistan \\ 'Department of Earth and Environmental Sciences, Bahria University Islamabad, 44000, Pakistan
}

(received April 3, 2019; revised January 8, 2020; accepted January 9, 2020)

\begin{abstract}
By using total organic carbon (TOC) and Rock-Eval pyrolysis analysis measurements, the hydrocarbon source rock potential of Chichali and Samana Suk formations found in the subsurface of Panjpir oilfield in Punjab platform located in the eastern part of the middle Indus Basin was investigated. Twenty two core samples were collected from producing well. The analysed samples of Chichali formation contains TOC ranging between $0.99-4.61 \mathrm{wt} . \%$ having average TOC of $1.51 \mathrm{wt} . \%$ and the S2 values of Rock-Eval show the poor to fair generative potential with values ranging from $0.99-3.08 \mathrm{mg} \mathrm{HC} / \mathrm{g}$ rock. The samples have low hydrogen index values ranging from 21-302 $\mathrm{mg} \mathrm{HC} / \mathrm{g}$ TOC and also most of the samples have low $\mathrm{T}_{-}(\max )$ values ranging from $422-432{ }^{\circ} \mathrm{C}$ and have OI values ranging from $15-82 \mathrm{mg}$ $\mathrm{CO}_{2} / \mathrm{g}$ TOC. Samana Suk formation samples have TOC ranging between 0.28-1.38 wt.\% having average TOC of 0.84 wt.\%. S2 values of Rock-Eval shows poor generative potential with values ranging from 0.05-2.99 $\mathrm{mg} \mathrm{HC} / \mathrm{g}$ rock. The samples have low hydrogen index values ranging from $13-322 \mathrm{mg} \mathrm{HC} / \mathrm{g}$ TOC and T_(max) values ranging from $423-435{ }^{\circ} \mathrm{C}$, and have OI values ranging from $41-182 \mathrm{mg} \mathrm{CO} / \mathrm{g}$ TOC. On the basis of analysis performed only one sample from Chichali and five samples of Samana Suk formations have entered early maturity zone, while all remaining samples lie in immature zone as indicated by HI vs T_(max) plot. HI vs OI plot and HI vs T_ $\max )$ indicates the presence of kerogen Type III. All of the samples from Samana Suk formation shows poor generative potential as compared to Chichali formation having fair generative potential as indicated by S2 vs TOC plot. Hence, from the results some minor gas could be expected to have been generated from Chichali formation in Panjpir oilfield subsurface.
\end{abstract}

Keywords: Punjab platform, TOC, thermal maturity, rock-eval, organic matter

\section{Introduction}

The Punjab platform is covered monocline dipping westward and is located in the middle Indus basin. The Sulaiman fold belt, Sulaiman depression and Punjab platform were split into three units in the middle Indus basin (Shah and Ahmed, 2018; Shah and Abdullah, 2016; Fazeelat et al., 2010; Raza et al., 2008). In middle Indus basin Punjab platform is the least succssful part and is dipping gently towards Sulaiman depression. The Punjab platform is bounded by Sargodha high by its north, Mari high from its south, from west Punjab platform merges into Sulaiman depression and in east it extends into Bikaner-Nagaur of India (Shah et al., 2018; Raza et al., 2008; Kadri, 1995). In this region various potential source rocks have been identified and gas was produced from those recognised source rock with kerogen Type II and III (Shah and Abdullah, 2017; Wandrey et al., 2004).

*Author for correspondence;

E-mail: bilawalshah22@yahoo.com
In the region three gas fields have been explored in the infra Cambrian sediments in the region having TOC up to $30 \%$ and ranging from $0.80-4 \% \mathrm{wt} . \%$, (Raza et al., 2008; Hasany et al., 2007; Peters et al., 1995).

Numerous formations in Punjab platform have the potential to produce hydrocarbons and acts as source rock (Shah and Ahmed, 2018; Fazeelat et al., 2010) i.e. Shinwari formation shales, Samana Suk limestone and Chichali formation of Mesozoic age. All of these have sufficient maturity to generate gas (Shah et al., 2019; Asim et al., 2014; Kadri, 1995). In this proven hydrocarbons province reservoiur rocks are Samana Suk, Shinwari and Datta formations, with discoveries at Meyal, Panjpir, Nandpur fields, and having seal provided by Ranikot shales (Asim et al., 2014).

Panjpir oil field is an important area and is host to proven hydrocarbon reserves but still hydrocarbons have not be explored as expected (Shah et al., 2018; Kadri, 1995). In this regards Chichali and Samana Suk 
formations which are proven source rocks in other parts of the basin also present in Panjpir oil field have been investigated in this study for hydrocarbons source rock potential. In this study twenty two samples of two formations Chichali and Samana Suk have been investigated to evaluate source rock potentiality.

Geological background. The Indian plate started to rift in Late Proterozoic from supercontinent Gondwanaland (Shah and Abdullah, 2017; Kemal et al., 1991; Raza et al., 2008), which resulted in sediment deposition of Infra-Cambrian over Pre-Cambrian. Due to the effect of dragging of Infra-Cambrian strata the second phase of rifting in Punjab platform is not evidently observable however, the evidence of rifting can be seen on reflectors of seismic profile, where cretaceous strata have been displaced along normal faults system, along with rifting the Indian plate collision and its subduction underneath the Eurasian plate which is still continuing, have developed variable structural patterns in Punjab platform (Kemal et al., 1991). Sedimentary rocks are not exposed on the surface since these are heavily covered by alluvium deposits of sand, clay and silt layers. In terms of petroleum exploration Punjab platform has received much more attention due to discovery of various gases and a recent oil field discovery in nearby field in neighbouring country India on this platform (Shah and Ahmed, 2018).

The study area Panjpir oil field is at lat $30^{\circ} 41^{\prime} 2.8104^{\prime \prime}$ $\mathrm{N} 71^{\circ}$ long $57^{\prime} 29.4012^{\prime \prime} \mathrm{E}$. The study area has revceived deformation as it lies directly above collusion zone (Eurasian and Indian Plate), where this basin merges into Suliman depression, greater part of the basin northeast is more like Potwar basin as both basins, stratigraphy is matchable, Fig. 1.

From drilling in Punjab platform, the stratigraphic succession has been established which shows mainly marine Palaeozoic-Cenozoic rocks of carbonates and clastic origin, however Punjab platform and Potwar basin stratigraphy of early Triassic age is similar, in southern part stratigraphy of both is very much comparable from Late Triassic and onwards (Shah, 2009; Raza et al., 2008).

\section{Material and Methods}

From well A in Punjab Platform a total of 22 core cutting samples were obtained at 2-3 m interval, the samples were of Cretaceous and Jurassic age. Samples detailes are available in Appendix 1.
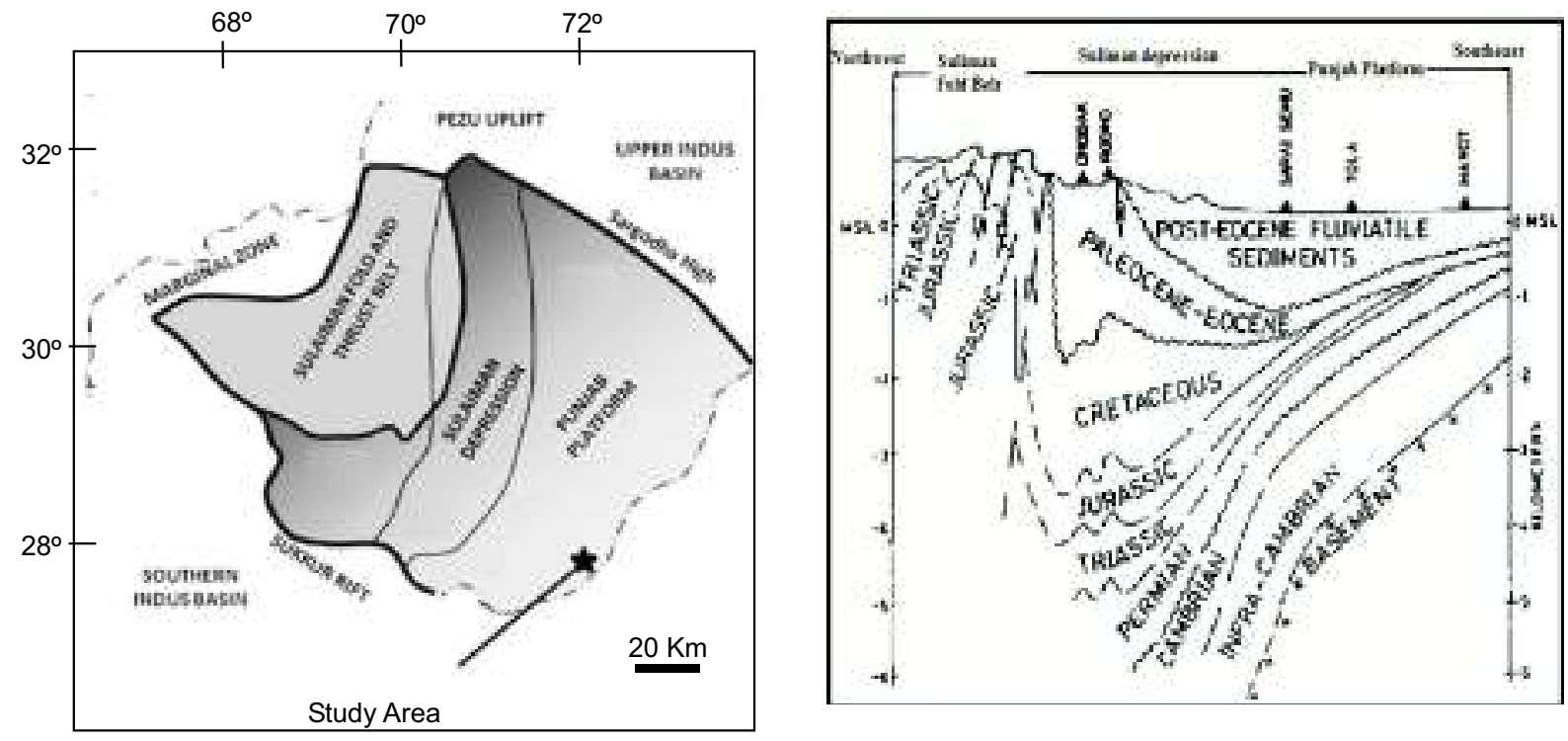

Retroeum Zone:

A1 = Punjab monocline; $\mathrm{B} 3$ = East sulaiman deprassion; $\mathrm{C} 1$ = Zindapir inner folded zone; $\mathrm{C} 2$ = Mart bugti inner folded zone; D1 = Sulaiman outer folded zone

Fig 1. Showing study area Panjpir oil field in the Punjab platform, middle Indus basin (Shah and Abdullah, 2018; modified after Asim et al., 2014; Kazmi and Snee, 1989). 
Samples were thoroughly washed with water and then dried, crushed and were subjected to passed through 80 $\mathrm{m}$ mesh sieve. The crushed samples were subjected to (TOC) total organic carbon analysis, and after TOC analysis the samples were further subjected to RockEval measurements, using Rock-Eval VI apparatus by following (Peters and Cassa, 1994; Peters, 1986). In a helium atmosphere the samples of $100 \mathrm{mg}$ were pyrolysed for $4 \mathrm{~min}$ at $300^{\circ} \mathrm{C}$, and followed by scheduled pyrolysis at $25^{\circ} \mathrm{C}$ per min from $300-550{ }^{\circ} \mathrm{C}$. The flame ionisation detector (FID) has been used for advance hydrocarbons tracking by (Tissot and Welte, 1984).

During isothermal pyrolysis at $300{ }^{\circ} \mathrm{C}$ from volatilization of free hydrocarbons the first peak S1 was obtained. S2 the second peak which represents hydrocarbons generated by thermal cracking of kerogen during pyrolysis at $300-500{ }^{\circ} \mathrm{C}$, and the third peak S3 which represents $\mathrm{CO}_{2}$ generated from $1 \mathrm{~g}$ of rock during pyrolysis were analysed by (TCF) thermal conductivity detector. Following Shah and Ahmed, (2018) and Fazeelat et al. (2010) maturity and type of organic matter were interpreted. The TOC measurements of rocks were determined by utilizing Leco CR-12 carbon determinator at (HDIP) Hydrocarbon Development Institute of Pakistan. To remove carbonate the crushed samples of $100 \mathrm{~g}$ were treated with $6 \mathrm{~N} \mathrm{HCL}$ and were combusted at $1200{ }^{\circ} \mathrm{C}$ in $\mathrm{O}_{2}$ atmosphere. By (TCD) thermal conductivity detector $\mathrm{CO}_{2}$ amount were measured.

\section{Results and Discussion}

Total organic carbon content and Rock-Eval pyrolysis. Cretaceous age Chichali and Jurassic age Samana Suk formations were assessed for source rock potential at well A in Panjpir oilfield, the calculated values are shown in Table 2.

TOC contents of the analysed samples of Chichali formations are generally in poor to fair potential range, having TOC between 0.99-4.61 wt. \%. From pyrolysis measurements the values of S2 of analysed sample are in poor to fair potential ranged from $0.99-3.08 \mathrm{mg} \mathrm{HC} / \mathrm{g}$ rock. According to the classification by Peters and Cassa (1994) these values are in the normal appropriate values of a source rock to have hydrocarbon generative

Appendix 1.

\begin{tabular}{llllllllll}
\hline \hline Depth $(\mathrm{m})$ & Formation & TOC $(\%)$ & $\mathrm{S} 1(\mathrm{mg} / \mathrm{g})$ & $\mathrm{S} 2(\mathrm{mg} / \mathrm{g})$ & $\mathrm{S} 3(\mathrm{mg} / \mathrm{g})$ & $\mathrm{Tmax}\left({ }^{\circ} \mathrm{C}\right)$ & $\mathrm{HI}$ & OI & S2/S3 \\
\hline 1675 & Chichali & 1.2 & 0.08 & 0.99 & 0.51 & 427 & 83 & 43 & 1.94 \\
1676 & Chichali & 4.61 & 0.1 & 0.99 & 0.68 & 427 & 21 & 15 & 1.46 \\
1678 & Chichali & 1.54 & 0.1 & 1.91 & 0.43 & 427 & 124 & 28 & 4.44 \\
1679 & Chichali & 1.57 & 0.08 & 2.75 & 0.57 & 427 & 175 & 36 & 4.82 \\
1681 & Chichali & 1.02 & 0.03 & 1.27 & 0.48 & 427 & 125 & 47 & 2.65 \\
1683 & Chichali & 1.53 & 0.03 & 1.15 & 0.76 & 422 & 75 & 50 & 1.51 \\
1685 & Chichali & 1.42 & 0.05 & 1.43 & 0.68 & 422 & 101 & 48 & 2.1 \\
1687 & Chichali & 1.02 & 0.03 & 3.08 & 0.68 & 426 & 302 & 67 & 4.53 \\
1694 & Chichali & 1.4 & 0.03 & 1.93 & 0.58 & 426 & 138 & 41 & 3.33 \\
1697 & Chichali & 1.34 & 0.03 & 1.71 & 0.68 & 432 & 128 & 51 & 2.51 \\
1701 & Chichali & 1.21 & 0.02 & 1.97 & 0.49 & 428 & 163 & 40 & 4.02 \\
1705 & Chichali & 1.23 & 0.02 & 1.97 & 1.01 & 428 & 160 & 82 & 1.95 \\
1708 & Chichali & 0.99 & 0.02 & 1.18 & 0.45 & 428 & 119 & 45 & 2.62 \\
1711 & Chichali & 1.1 & 0.02 & 1.13 & 0.41 & 428 & 103 & 37 & 2.76 \\
1752 & Samana Suk & 1.38 & 0.02 & 0.23 & 0.63 & 428 & 17 & 46 & 0.37 \\
1754 & Samana Suk & 1.09 & 0.02 & 0.69 & 0.85 & 423 & 63 & 78 & 0.81 \\
1756 & Samana Suk & 1.08 & 0.02 & 0.14 & 0.44 & 423 & 13 & 41 & 0.32 \\
1758 & Samana Suk & 0.93 & 0.02 & 2.99 & 0.54 & 434 & 322 & 58 & 5.54 \\
1760 & Samana Suk & 0.52 & 0.01 & 0.15 & 0.66 & 433 & 130 & 127 & 0.23 \\
1762 & Samana Suk & 0.89 & 0.05 & 0.14 & 0.68 & 434 & 16 & 76 & 0.21 \\
1763 & Samana Suk & 0.28 & 0.01 & 0.05 & 0.51 & 435 & 18 & 182 & 0.1 \\
1765 & Samana Suk & 0.56 & 0.02 & 0.35 & 0.39 & 433 & 63 & 70 & 0.9 \\
\hline \hline
\end{tabular}

TOC $=$ total organic carbon, wt.\% TOC; $\mathrm{S} 1$ = volatile hydrocarbon $(\mathrm{HC})$ content, $\mathrm{mg} \mathrm{HC} / \mathrm{g}$ rock; S3 = carbon dioxide yield, $\mathrm{mg} \mathrm{CO}_{2} / \mathrm{g}$ rock; $\mathrm{HI}=$ hydrogen index $=\mathrm{S} 2 \times 100 / \mathrm{TOC}, \mathrm{mg} \mathrm{HC} / \mathrm{g} \mathrm{TOC} ; \mathrm{OI}=$ oxygen index $=\mathrm{S} 3 \times 100 / \mathrm{TOC}, \mathrm{mg} \mathrm{CO}_{2} / \mathrm{g}$; $\mathrm{S} 2$ = remaining $\mathrm{HC}$ generative potential, $\mathrm{mg} \mathrm{HC} / \mathrm{g}$ rock; $\mathrm{T}_{\max }=$ temperature at maximum $\mathrm{S} 2$ peak. 
potential. These samples have reasonal potential as indicated by S2 vs TOC plot (Fig. 2), whereas only one sample lies in poor range. The samples also have mostly low $\mathrm{HI}$ values ranging from 21-302 $\mathrm{HC} / \mathrm{g} \mathrm{TOC}$, and have OI values ranging from $15-82 \mathrm{mg} \mathrm{CO} / \mathrm{g}$ TOC having kerogen Type III (Fig. 3). of the analysed samples which represent the temperature at the point, where S2 peak is at its maximum have values ranging from 422 $432{ }^{\circ} \mathrm{C}$ indicating that the samples are immature and lie in immaturity window, with only one sample that has entered early maturity window. For thermal maturity HI vs $\mathrm{T}_{\max }$ were plotted which show that most of the samples lie in immature zone and only one sample shows maturity (Fig. 4). However, Samana Suk formation have poor generative potential having TOC ranging from $0.28-1.38 \mathrm{wt} . \%$, S2 values ranging from $0.05-2.99$ $\mathrm{mg} \mathrm{HC/g}$ rock and low $\mathrm{HI}$ values ranging from 13-322 $\mathrm{HC} / \mathrm{g}$ TOC, indicating that the samples have poor potential to generate hydrocarbons (Fig. 2-4).

The data shows the Samana Suk formation sediments have poor generation potential as compared to Chichali formation sediments which have poor to good generative after the analysis of samples potential. By pyrolysis data, the type of organic matter and the hydrocarbons

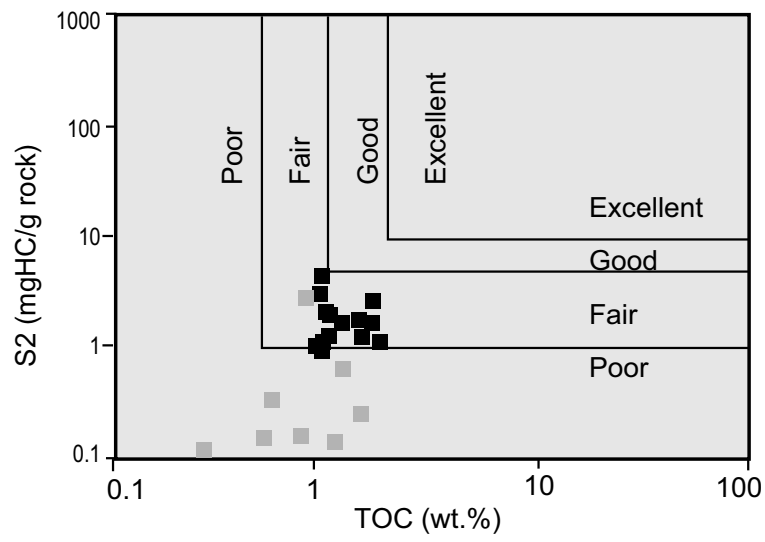

- Chichali formation samples;

- Samana Suk formation samples

Fig. 2. Pyrolysis S2 versus (TOC) total organic carbon plot displaying source rock generative potential (after Peters and Cassa, 1994).

Table 1. Log based tratigraphy of Panjpir oil fied (developed from well 1)

\begin{tabular}{lllll}
\hline \hline Age & Formation & Lithology & Top (m) & Bottom (m) \\
\hline Pliocene & Nagri & Sandstone & 0 & 620 \\
Miocene & Chinji & Sandstone and clay & 620 & 1326 \\
Eocene & Sakesar & Limestone & 1326 & 1326 \\
Early eocene & Nammal & Shale and marl & 1326 & 1360 \\
Early eocene & Ghazij Sui member & Shale & 1360 & 1521 \\
Paleocene & Dunghan & Limestone & 1521 & 1542 \\
Paleocene & Ranikot & Limestone and shale & 1542 & 1602 \\
Cretaceous & Lumshiwal & Sandstone and silt stone & 1602 & 1672 \\
Cretaceous & Chichali & Silt stone and sandstone & 1672 & 1727 \\
Middle jurassic & Samanasuk & Sandstone and limestone & 1727 & 1854 \\
Early jurassic & Shinwari & Sandstone and siltstone & 1854 & 1931 \\
Early jurassic & Datta & Sandstone and shale & 1931 & 1949 \\
Late triassic & Kingriali & Dolomite limestone & 1949 & 2077 \\
Middle triassic & Tredian & Sandstone & 2077 & 2120 \\
\hline \hline
\end{tabular}

Table 2. Measure TOC and Rock-Eval pyrolysis measurements

\begin{tabular}{|c|c|c|c|c|c|c|c|c|c|}
\hline \multirow{2}{*}{$\begin{array}{l}\text { Formation } \\
\text { (no. of samples) }\end{array}$} & \multirow[t]{2}{*}{ Depth (m) } & \multicolumn{3}{|c|}{ Hydrocarbon potential } & \multirow{2}{*}{$\begin{array}{l}\text { Maturity } \\
\operatorname{Tmax}{ }^{\circ} \mathrm{C}\end{array}$} & \multicolumn{2}{|c|}{ OM Quality } & \multirow{2}{*}{$\begin{array}{l}\text { Main } \\
\text { Kerogen } \\
\text { type }\end{array}$} & \multirow{2}{*}{$\begin{array}{l}\text { Source } \\
\text { rock } \\
\text { potential }\end{array}$} \\
\hline & & TOC \% & S1 & S2 & & $\overline{\mathrm{HI}}$ & $\mathrm{S} 2 / \mathrm{S} 3$ & & \\
\hline $\begin{array}{l}\text { Chichali } \\
\text { formation (14) }\end{array}$ & $1676-1711$ & $0.99-4.61$ & $0.08-0.10$ & $0.99-3.08$ & $422-432$ & $21-302$ & $1.45-4.82$ & III & Poor-Fair \\
\hline $\begin{array}{l}\text { Samana } \\
\text { Suk (08) }\end{array}$ & $1752-1765$ & $0.28-1.38$ & $0.01-0.05$ & $0.05-2.99$ & $423-435$ & $13-322$ & $0.10-5.54$ & III & Poor \\
\hline
\end{tabular}


that may have been generated by Chichali and Samana Suk formations have been characterized. According to Hunt (1995) the sediments that have Type III kerogen are expected to have generated gas with HI values less

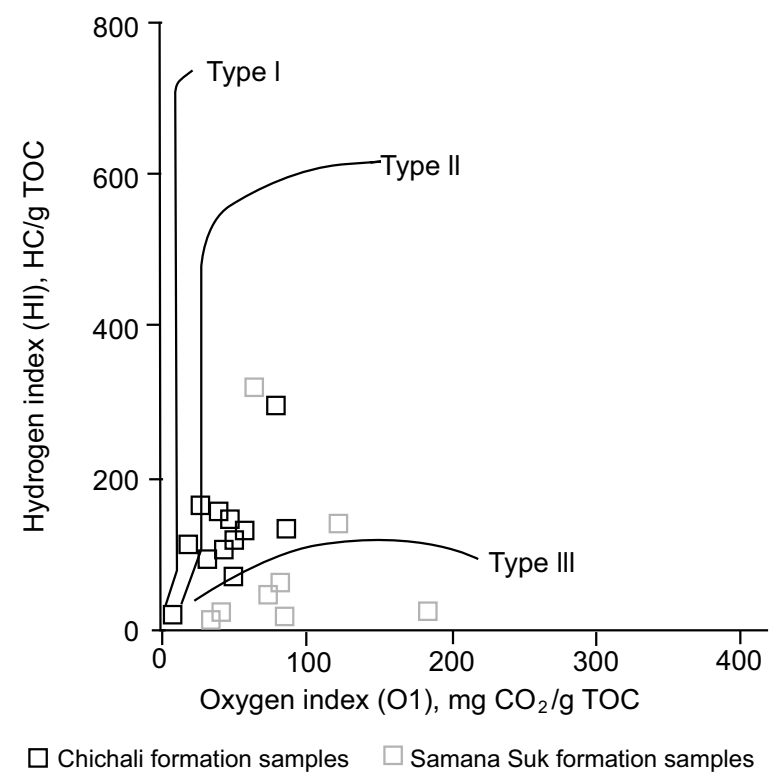

Fig. 3. Plot of HI $v s$ OI showing type of organic matter of analysed samples.

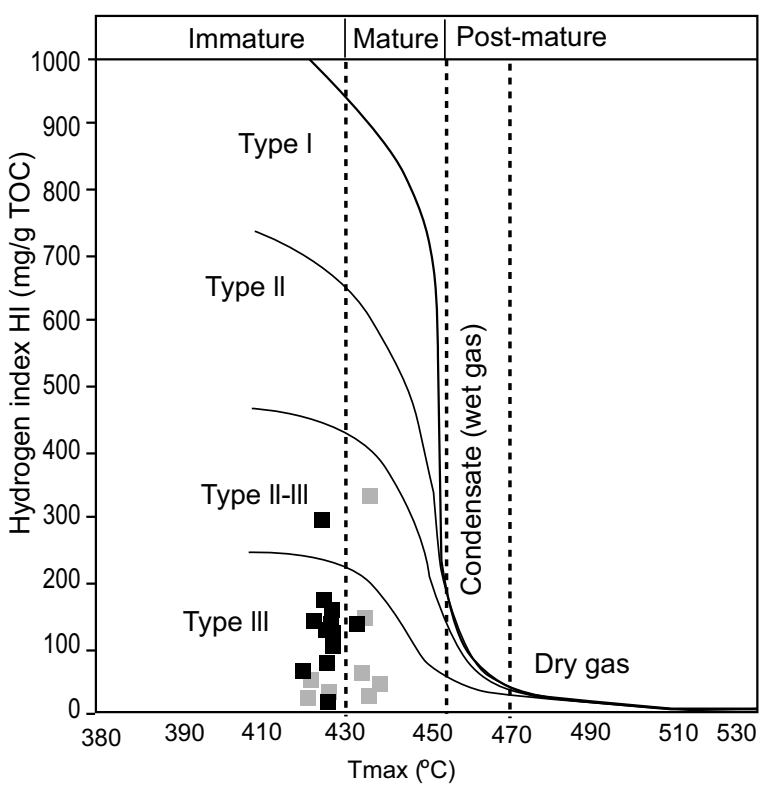

Chichali formation samples Samana Suk formation samples

Fig. 4. (HI) versus $T_{\max }$ displaying thermal maturity and kerogen quality of the analysed samples. than $200 \mathrm{mg} \mathrm{HC} / \mathrm{g}$ TOC, whereas HI values greater than $300 \mathrm{mg} \mathrm{HC} / \mathrm{g}$ TOC along with TOC values greater than $1 \mathrm{wt} . \%$ should generate oil. The analysed samples of Chichali and Samana Suk formations have average TOC 1.51 and $0.84 \%$ and have average HI values 129 and $80 \mathrm{mg} \mathrm{HC} / \mathrm{g}$ TOC having Type III kerogen. The analysed Chichali formation is considered to have a poor to fair generative potential and gas could be expected to have been generated by Chichali formation, however analysed Samana Suk formation have poor generative potential.

\section{Conclusions}

The investigation of Chichali and Samana Suk formations sediments shows poor generative potential for oil, which is indicated by S2 values which are ranging from $0.05-3.08 \mathrm{mg} \mathrm{HC} / \mathrm{g}$ rock and low $\mathrm{HI}$ values ranging from $13-322 \mathrm{HC} / \mathrm{g}$ TOC, and have OI values ranging from $15-182 \mathrm{mg} \mathrm{CO} / \mathrm{g}$ TOC, having kerogen Type III as indicated by HI vs OI plot and HI vs plot. Only one sample of Chichali formation and five from Samana Suk formation shows early maturity window as indicated by HI vs Tmax plot. Chichali formation samples have TOC values ranging from 0.28 $4.61 \mathrm{wt} . \%$ having average TOC of $1.51 \mathrm{wt} . \%$. Therefore, some minor gas could be expected to have been generated from Chichali formation, whereas Samana Suk formation have poor generative potential.

Future recommendations. Chichali and Samana Suk formations can be further investigated by using advanced techniques like Py-GC, GC-MS, microfacies analysis and biomaker study for depositional and enviromental factors.

\section{Acknowledgment}

The authors are thankful to the Directorate General Petroleum Concession, Pakistan (DGPC) for the provision of data, OGDCL for providing the samples, and University of Malaya for lab analysis.

Conflict of Interest. The authors declare no conflict of interest.

\section{References}

Asim, S., Qureshi, S.N., Asif, S.K., Abbasi, S.A., Solangi, S., Mirza, M.Q. 2014. Structural and stratigraphical correlation of seismic profiles between Drigri Anticline and Bahawalpur high in 
central Indus basin of Pakistan. International Journal of Geosciences, 5: 1231-1240.

Fazeelat, T., Jalees, M.I., Bianchi, T.S. 2010. Source rock potential of eocene, paleocene and Jurassic deposits in the subsurface of the Potwar basin, northern Pakistan. Journal of Petroleum Geology, 33: $87-96$.

Hasany, S.T., Aftab, M., Siddiqui, R.A. 2012. In: Proceeding of Refound Exploration Opportunities in Infracambrian and Cambrian Sediments of Punjab Platform, Pakistan. Annual Technical Conference, Islamabad, Pakistan, 1: 31-62.

Hunt, J.M. 1995. Petroleum Geochemistry and Geology, Freeman, W. H. \& Co., $2^{\text {nd }}$ edition, vol. 1, 743 pp., New York, USA.

Kadri, I.B. 1995. Petroleum Geology of Pakistan, pp. 11-203, Pakistan Petroleum Limited Karachi, Pakistan, $275 \mathrm{pp}$.

Kazmi, A.H., Snee, L.W. 1997. Geology, Gemology and Genesis, 1: 4-11, Emerald of Pakistan, Pakistan.

Kemal, A., Balkwill, H.R., Stoakes, F.A. 1991. Indus basin hydrocarbon plays. In: International Petroleum Seminar on New Directions and Strategies for Accelerating Petroleum Exploration and Production in Pakistan, pp. 16-57.

Peters, K.E, Clark, M.E., Das Gupta, U., McCaffrey, M.A., Lee, C.Y. 1995. Recognition of an infracambrian source rock based on biomarkers in the Baghewala-1 oil, India. American Association of Petroleum Geologists Bulletin, 79: 1481-1494.

Peters, K.E., Cassa, M.R. 1994. Applied source rock geochemistry. In: The Petroleum System-From Source to Trap, Magoon, L.B., Dow, W.G. (eds.), American Association of Petroleum Geologists Memoir, 60: 93-120.

Peters, K.E. 1986. Guidelines for evaluating petroleum source rock using programmed pyrolysis. American Association of Petroleum Geologists Bulletin, 70: 318-329.
Raza, H.A., Ahmad, W., Ali, S.M., Mujtaba, M., Alam, S., Shafeeq, M., Riaz, N. 2008. Hydrocarbon prospects of Punjab platform Pakistan, with special reference to Bikaner-Nagaur Basin of India. Pakistan Journal of Hydrocarbon Research, 18: 1-33.

Raza, H.A., Ahmed, R., Alam, S., Ali, S.M. 1989. Petroleum zones of Pakistan. Pakistan Journal of Hydrocarbon Research, 1: 1-20.

Shah, S.B.A., Abdullah, W.H., Shuib, M.K.B. 2019. Petrophysical properties evaluation of Balkassar oil field, Potwar Plateau, Pakistan, implication for reservoir characterisation. Himalayan Geology, 40: 50-57.

Shah, S.B.A., Ahmed, A. 2018. Hydrocarbon source rock potential of Paleocene and Jurassic deposits in the Panjpir oil field subsurface, Punjab platform, Pakistan. Arabian Journal of Geosciences, 11: 607 .

Shah, S.B.A., Abdullah, W.H. 2017. Structural interpretation and hydrocarbon potential of Balkassar oil field, eastern Potwar, Pakistan, using seismic 2D data and petro physical analysis. Journal of the Geological Society of India, 90: 323-328.

Shah, S.B.A., Abdullah, W.H. 2016. Petrophysical properties and hydrocarbon potentiality of Balkassar well 7 in Balkassar oil field, Potwar Plateau, Pakistan. Bulletin of the Geological Society of Malaysia, 62: 73-77.

Shah, S.I. 2009. Stratigraphy of Pakistan, pp. 3-150, Government of Pakistan Ministry of Petroleum \& Natural Resources Geological Survey of Pakistan.

Tissot, B.P., Welte, D.H. 1984. Petroleum Formation and Occurrenc, $2^{\text {nd }}$ eds, vol. 699, pp. 25-140, Springer Berlin.

Wandrey, C.J., Law, B.E., Shah, H.A. 2004. PatalaNammal composite total petroleum system, KohatPotwar geologic province, Pakistan. US Geological Survey, 1: 1-18. 